\title{
Assessment of food security in the region in the context of the development of the agro- industrial complex (on the example of the Sverdlovsk region)
}

\author{
Aleksey Pestryakov, Ekaterina Reutova, Nadezhda Sbrodova, and Alisa Titovets* \\ Ural State University of Economics, 620144 Yekaterinburg, Russia
}

\begin{abstract}
Ensuring food security and promoting agricultural development are included in the priority goals of sustainable development until 2030. The structural complexity and multidimensionality of food security in the region requires a clear methodology for its assessment. The article provides an overview of the advantages and disadvantages of existing methods for assessing the food security of a region in the Russian Federation. The authors proposed a methodology for assessing the food security of a region, which makes it possible to translate the qualitative characteristics of indicators into a unified quantitative characteristic, by considering three possible options for interpreting the indicators. This makes it possible to form a final aggregate assessment of the level of food security in the region and track it in dynamics through the prism of the development of the agro-industrial complex.
\end{abstract}

\section{Introduction}

The food security of the state is formed from the level of self-sufficiency of each region, as well as the state of the agro-industrial complex in each individual territory. The lack of food can cause severe social upheavals, while full security serves as the basis for the stability and balance of the development of the state [1]. It should noted that one of the goals of sustainable development until 2030 is The goal is to end hunger, ensure food security and improve nutrition, and promote sustainable agriculture.

In recent years, the policy of import substitution and increasing self-sufficiency in food has been carried out on the territory of all subjects of the Russian Federation, in particular, the Sverdlovsk Region. This political orientation is due to the commitment of the Russian economy to external influence from the main importers, as well as the problem of the whole world, which consists in food shortages. As a result, the agro-industrial complex plays a huge role in ensuring the food security of both the region and the country as a whole. Therefore, the sustainable development of agriculture is of key importance for improving food security [2].

\footnotetext{
* Corresponding author: alisa.titovets@mail.ru
} 
For the first time, the term "food security" was used in 1974 in Rome, at the World Conference on Food Problems, organized by the Food and Agriculture Organization of the United Nations after a sharp increase in world grain prices. The essence of food security was defined 20 years later, in 1996, in the Rome Declaration on World Food Security: this is "... a state of the economy in which the population of the country as a whole and each individual citizen is guaranteed access to food, drinking water and other food products in the quality, range and volume necessary and sufficient for the physical and social development of the individual, ensuring health and expanded reproduction of the population of the country " [3].

The interpretation of the concept of "food security of the region" is currently not uniform, although when analyzing the definitions presented in different sources, one can note similar features: all authors agree that ensuring the food security of the region expresses the availability of food in the required volume and quality requirements [4]. In our opinion, the following definition would be optimal: the food security of a region is a state of the economy, in which the availability of high-quality food products to the entire population living in a given territory is ensured in an appropriate volume.

The food security of the region depends on the influence of factors at various levels of the hierarchy:

- factors of the world community (mega-level);

- states (macro level);

- factors of influence of neighboring regions;

- agro-industrial complex (AIC) of the region (meso-level);

- households (micro level) [5].

Our research is focused on ensuring the food security of the region in the context of the activities of its agro-industrial complex, since providing the population with highquality food products necessary for active social and economic reproduction is the main task of the agro-industrial and agricultural policy of any state [6]. Proceeding from the fact that in the scientific community there is almost literal agreement in the interpretation of the agro-industrial complex, and all existing definitions almost exactly repeat each other, we will understand the definition given by T.V. Uskovoy: "this is the largest intersectoral complex, uniting several sectors of the economy, aimed at the production and processing of agricultural raw materials and obtaining products from it, brought to the end consumer" [7].

\section{Materials and methods}

Researchers note the importance of improving the methods for assessing the food security of the region, taking into account the facilitation of their practical application [8,9]. Poorly designed measurement tools create confusion and can have negative implications for food security [10]. In addition, in the methods of assessing food security, it is important to take into account regional characteristics [11], since the model for ensuring food security may differ in different countries and regions of the world and depend on many factors $[1,12]$. All this casts doubt on the appropriateness of simply transferring national food security assessment methodologies to other levels of activity.

Currently, in the Russian Federation there is no single methodology for assessing the food security of the region, so we studied the most well-known of the available methods. This is the system of indicators "Doctrine of food security", the methodology proposed by the Institute of Socio-Economic Development of Territories of the Russian Academy of Sciences, as well as the indicators set out in the law of the Sverdlovsk region of January 31, 2012 N 6-OZ "On ensuring food security of the Sverdlovsk region."

All of these techniques have, of course, a number of advantages: 
- the complexity and comprehensiveness of assessing the state of food security in the region;

- the clarity and feasibility of the proposed indicators.

Nevertheless, the analysis showed a number of noticeable shortcomings in each of the techniques.

The Food Security Doctrine, proposed by the Ministry of Economic Development of the Russian Federation and approved by the President, contains indicators for assessing food security that are not applicable at the regional level for several reasons: lack of relevant regional statistical data; inadaptation for specific industries of a specific territory; lack of a final assessment of the state of food security.

When analyzing the methodology of the Institute of Socio-Economic Development of Territories of the Russian Academy of Sciences, a number of nuances were also identified that exclude the possibility of full use of the methodology for assessing the food security of the region [13]: lack of relevant regional statistical data; the complexity of mathematical calculations of indicators; the absence of a method for interpreting qualitative indicators in the final assessment of the state of food security in the region. In addition, this system of indicators differs significantly from the systems of indicators enshrined in regulatory legal acts, both on the territory of individual regions and on the territory of the entire Russian Federation.

The main drawback of the system of indicators developed in the Sverdlovsk region on the basis of the Doctrine of food security and enshrined in the law "On ensuring food security of the Sverdlovsk region" is the lack of a final assessment of the state of food security in the region.

Nevertheless, we propose to use this particular methodology, and the identified "weak side" is proposed to be filled on the basis of the author's interpretation of the indicators. This is necessary in order to holistically reflect the current state of food security in the region on the basis of the proposed indicators, not only in a qualitative version, but also in a quantitative one.

We propose a methodology for translating indicators, which have mainly qualitative characteristics, into a quantitative version, with the aim of a more visual and objective assessment. We rely on the scoring system proposed by the Russian Academy of Sciences, as well as on methodological recommendations for assessing the economic security of the region of the Ural State University of Economics. Points are awarded for each individual sub-industry in the indicator, if any.

The system for assessing each of the indicators for ensuring the food security of the region with comments is presented in Table 1 . We have identified three possible options for interpreting the indicators, each requiring a special approach..

Table 1. Criteria for assessing the indicators of ensuring food security in the region.

\begin{tabular}{|c|c|c|c|}
\hline $\begin{array}{c}\text { Number of } \\
\text { points } \\
\text { assigned }\end{array}$ & $\begin{array}{c}\text { Option 1 } \\
\text { (If there are thresholds, } \\
\text { norms, percentages of plan } \\
\text { implementation) }\end{array}$ & $\begin{array}{c}\text { Option 2 } \\
\text { (In the absence of } \\
\text { threshold values, } \\
\text { assessment of the } \\
\text { dynamics of indicators) }\end{array}$ & $\begin{array}{c}\text { Option 3 (assessment of } \\
\text { the indicator structure) }\end{array}$ \\
\hline 0 & $\begin{array}{c}\text { Non-fulfillment of planned } \\
\text { indicators (subject to an } \\
\text { objectively drawn up plan), } \\
\text { non-fulfillment of threshold } \\
\text { and normative indicators }\end{array}$ & $\begin{array}{c}\text { The dynamics of the } \\
\text { decline in the previous } \\
5 \text { years }\end{array}$ & $\begin{array}{c}\text { Changes in the structure or } \\
\text { its current state can lead to } \\
\text { adverse consequences, } \\
\text { increased risks for the } \\
\text { agro-industrial complex }\end{array}$ \\
\hline 1 & $\begin{array}{c}\text { Fulfillment of normative or } \\
\text { planned indicators at the } \\
\text { level of 100\%. }\end{array}$ & $\begin{array}{c}\text { Maintaining indicators } \\
\text { at the same level for 5 } \\
\text { years, stagnation }\end{array}$ & $\begin{array}{c}\text { The structure is in a } \\
\text { normal ratio }\end{array}$ \\
\hline 2 & Fulfillment of normative or & Growth of indicators & The structure is in the \\
\hline
\end{tabular}




\begin{tabular}{|c|c|c|c|}
\hline & $\begin{array}{c}\text { planned indicators in excess } \\
\text { of the established values }\end{array}$ & on an annual basis & optimal ratio \\
\hline
\end{tabular}

We propose to assign different levels of food security to the region according to the scale presented in Table 2.

Table 2. Aggregate assessment of the state of the study area.

\begin{tabular}{|c|l|}
\hline $\begin{array}{c}\text { \% of the maximum number of } \\
\text { points }\end{array}$ & \multicolumn{1}{|c|}{ The state level of the sphere under study } \\
\hline $1-23 \%$ & Class V: unacceptably low level of food security \\
\hline $24-55 \%$ & Class IV: low level of food security \\
\hline $56-77 \%$ & $\begin{array}{l}\text { Class III: satisfactory (acceptable, acceptable) level of food } \\
\text { security }\end{array}$ \\
\hline $78-89 \%$ & Class II: high level of food security \\
\hline $90-100 \%$ & Class I: optimal level of food security \\
\hline
\end{tabular}

On the basis of the proposed system for assessing the state of food security in the region, it is possible to comprehensively characterize the current situation of the analyzed territory, as well as to more clearly trace the dynamics of the development of the level of food security in the region through the prism of the development of the agro-industrial complex.

\section{Results and discussion}

The activity of the agro-industrial complex of the Sverdlovsk region is largely determined by the pace of development of agriculture, which is not a branch of specialization, due to difficult natural and climatic conditions, and provides $2.36 \%$ of GRP. This means that the issue of ensuring food security in the region is a priority.

To assess the state of food security in the Sverdlovsk region in the context of the development of the agro-industrial complex, we rely on the previously announced methodology.

Indicator 1. Food consumption per capita in dynamics. In the Sverdlovsk region, an increase in the consumption of such food products as potatoes, bread and meat products was recorded. We use the second version of the evaluation criteria from the proposed methodology.

Indicator 2. The ratio of rational norms of food consumption and actually consumed food products per capita is estimated according to the first version of the interpretation of indicators (Table 3).

Table 3. Economic availability of food in the Sverdlovsk region in 2018, \%.

\begin{tabular}{|c|c|c|c|}
\hline & $\begin{array}{c}\text { Rational consumption } \\
\text { rates per person per year }\end{array}$ & $\begin{array}{c}\text { Actual food } \\
\text { consumption per } \\
\text { capita per year, kg: }\end{array}$ & $\begin{array}{c}\text { Economic } \\
\text { accessibility } \\
\text { of food, } \%\end{array}$ \\
\hline $\begin{array}{c}\text { Meat and meat products, } \\
\text { including offal }\end{array}$ & 73 & 78 & $107 \%$ \\
\hline Milk and dairy products & 325 & 240 & $74 \%$ \\
\hline Potatoes & 90 & 97 & $108 \%$ \\
\hline $\begin{array}{c}\text { Vegetables and food } \\
\text { melons }\end{array}$ & 140 & 95 & $69 \%$ \\
\hline Bread products & 96 & 122 & $127 \%$ \\
\hline Eggs & 260 & 234 & $90 \%$ \\
\hline
\end{tabular}


In the territory of the Sverdlovsk region, the consumption of bread products (namely, confectionery products, since their volume is growing significantly) is higher than normal and has been gradually increasing for the last 5 years since 2014. This can have a negative impact not only on the health of the population, but also on the food security of the region, since the growth of the raw material base for the production of this type of product is not noted. This means that it may be necessary to purchase raw materials in other regions or countries, which will significantly affect the level of self-sufficiency, as one of the indicators of the state of the agro-industrial complex and food security.

It should also be noted that the production and consumption of vegetables in the region, although increasing, is not at the proper level, which again can negatively affect both health and food security.

Indicator 3. The consumer price index for food products, in particular, the annual index, in our opinion, is not quite indicative for analysis, since it does not reflect significant seasonal fluctuations in prices for various types of products. In the territory of the Sverdlovsk region, there was a significant increase in prices in the short term for potatoes, which, in turn, also negatively affects the state of food security.

Indicator 4. The production volumes of agricultural and fish products, raw materials and food products are estimated according to the second option from the proposed methodology.

Indicator 5. The volume of sales of food products by trade and public catering organizations is presented in Table 4. Assessing the ratio of production and sales of agricultural products in accordance with the third version of the interpretation of indicators, we can conclude about the existing disparities between livestock and crop production.

The first (livestock and poultry, milk, eggs) is sold at a fairly high level, the second (potatoes and vegetables) has a fairly low performance.

Table 4. Volume of production and sales of agricultural products in the territory of the Sverdlovsk region, 2018.

\begin{tabular}{|c|c|c|c|}
\hline & $\begin{array}{c}\text { Production } \\
\text { volume }\end{array}$ & $\begin{array}{c}\text { Sales } \\
\text { volume }\end{array}$ & \% of sales from total production \\
\hline $\begin{array}{c}\text { Livestock and poultry for } \\
\text { slaughter (live weight), thousand } \\
\text { tons }\end{array}$ & 274,4 & 249,1 & $90,8 \%$ \\
\hline Milk, thousand tons & 762,5 & 670,3 & $87,9 \%$ \\
\hline Eggs, million pieces & 1571,2 & 1378,4 & $87,7 \%$ \\
\hline Potato & 738,7 & 221,5 & $30 \%$ \\
\hline Vegetables & 200,5 & 59,4 & $29,6 \%$ \\
\hline
\end{tabular}

On the part of vegetable products, this is primarily due to the low level of consumption presented earlier. Analyzing the indicators of potato production and sales, we can draw a conclusion about the storage of products produced in the region. This is due to the specifics of the internal food policy of the region, aimed at avoiding mass export of goods outside the region. The purpose of such a policy is to reduce the risks associated with a shortage of crops in the spring period, which leads to an increase in prices.

Indicator 6. The volume of imports of agricultural and fish products, raw materials and food products to the territory of the Sverdlovsk region. The main trade partner of the region in this direction is the Republic of Kazakhstan. At the same time, food imports in 2018 accounted for only $3 \%$ of total consumption. Accordingly, we can conclude that the level of import dependence is low. Most of the import is made up of products from neighboring regions, as well as regions of Russia that specialize in agricultural activities.

Indicator 7. The share of low-quality and dangerous food products from the total number of food samples tested in the framework of state supervision in the field of food 
quality and safety in 2018 is significantly lower than in 2016 (Table 5). This means reducing the risks to public health, reducing the costs of producers due to court proceedings, increasing the competitiveness of enterprises, that is, creating a basis for improving the level of food security.

Table 5. Specific weight of low-quality and dangerous products.

\begin{tabular}{|c|c|c|c|}
\hline Product Type & 2018 & 2016 & 2010 \\
\hline Dairy products & $7,3 \%$ & $22,4 \%$ & $6,2 \%$ \\
\hline Alcoholic beverages & $1,2 \%$ & $20,4 \%$ & $9,3 \%$ \\
\hline Meat products & $6,1 \%$ & $12,8 \%$ & $13,1 \%$ \\
\hline Fish products & $2,5 \%$ & $21,9 \%$ & $19,0 \%$ \\
\hline Fat and oil products & $2,3 \%$ & $6,2 \%$ & $8,1 \%$ \\
\hline Confectionery products & $15,1 \%$ & $28,2 \%$ & $17,3 \%$ \\
\hline Bakery products & $17,1 \%$ & $17,6 \%$ & $27,2 \%$ \\
\hline
\end{tabular}

Indicator 8 . The volume of state social assistance to low-income families and lowincome single citizens in 2018 amounted to 574.4 million rubles for 228,938 residents (5.3\% of the total population) of the Sverdlovsk region, that is, approximately 2509 rubles per year per person, 209.08 rubles per month. From 01.01.2020, the minimum amount of social benefits is 493 rubles per month for each family member, that is, the amount of support, in accordance with the first version of the assessment of indicators, may be considered insufficient.

Indicator 9. State support for legal entities and individuals engaged in the production of agricultural products, including its processing, and (or) the purchase of agricultural products, food and forest resources, based on the ruble of products sold in 2018 amounted to $6.53 \%$. For a more detailed analysis, 19 agribusiness companies operating in the Sverdlovsk region and producing more than $1 \%$ of the total volume of agricultural products were taken. These companies account for $35 \%$ of all government support provided in the region. The largest share of state support in 2018 was provided by Teplichnoye JSC, which is part of UMMC-Holding LLC. This company is the largest in the Sverdlovsk region for the production of crop production, and at the moment, at the expense of the federal budget and the budget of the Sverdlovsk region, it is upgrading and expanding production. Since this enterprise is engaged in growing vegetables in closed ground, and for this position, as it was shown earlier, there is a significant lack of both production and consumption by the population in the region, this change can positively affect the food security of the region in a number of indicators.

Indicator 10 . The availability of retail space and catering facilities per 1,000 people is estimated in Table 6 in accordance with the first interpretation of the indicators.

Table 6. Availability of retail space and catering facilities in the Sverdlovsk region in 2018.

\begin{tabular}{|c|c|c|}
\hline Name of indicators & Standard indicator & Actual indicator \\
\hline $\begin{array}{c}\text { Population provision with the area } \\
\text { of retail spaces used for the } \\
\text { implementation of activities for the } \\
\text { sale of food products in the retail } \\
\text { markets of the Sverdlovsk region }\end{array}$ & 0.64 retail space per \\
1000 inhabitants & $\begin{array}{c}0.34 \text { retail space per } 1000 \\
\text { residents }\end{array}$ \\
$\begin{array}{c}\text { The standard reached only in } \\
\text { three municipalities (Asbestovsky } \\
\text { city district, Karpinsk city district, } \\
\text { Novouralsky City District) }\end{array}$ \\
\hline $\begin{array}{c}\text { Availability of retail space in public } \\
\text { catering establishments }\end{array}$ & $\begin{array}{c}66.3 \text { square meters per } \\
1000 \text { inhabitants }\end{array}$ & $\begin{array}{c}\text { 60.6 square meters per } 1000 \\
\text { inhabitants }\end{array}$ \\
\hline \multicolumn{2}{|c}{} & \multicolumn{2}{|c|}{} \\
\hline
\end{tabular}


Summarizing the analysis carried out in accordance with our methodology, we compare the results obtained in the general table 7, which gives a quantitative assessment of the food security of the Sverdlovsk region in dynamics for 2016-2018. 
Table 7. Assessment of food security in the Sverdlovsk region.

\begin{tabular}{|c|c|c|c|c|}
\hline Indicators & $\begin{array}{l}\text { Maximum } \\
\text { score }\end{array}$ & $\begin{array}{l}\text { Actual score } \\
\text { in } 2018\end{array}$ & $\begin{array}{l}\text { Actual } \\
\text { score in } \\
2016\end{array}$ & Comment \\
\hline 1 & 10 & 7 & 6 & $\begin{array}{l}\text { Out of } 5 \text { food products, dairy } \\
\text { products are in a state of stagnation } \\
\text { in terms of consumption, while meat } \\
\text { products, bakery products and } \\
\text { potatoes are growing. At the same } \\
\text { time, the consumption of vegetables } \\
\text { in the region is reduced. }\end{array}$ \\
\hline 2 & $\begin{array}{l}12(2 \text { points } \\
\text { for each type } \\
\text { of product }) \\
\end{array}$ & 6 & 6 & $\begin{array}{l}\text { The actual consumption of food in } \\
\text { the territory of the region for } 3 \text { types } \\
\text { of products was lower than the norm }\end{array}$ \\
\hline 3 & $\begin{array}{l}14 \text { ( } 2 \text { points } \\
\text { for each type } \\
\text { of product })\end{array}$ & 12 & 14 & $\begin{array}{l}\text { The consumer price index for all } \\
\text { types of products (with the exception } \\
\text { of potatoes) did not exceed the } \\
\text { threshold values }\end{array}$ \\
\hline 4 & 24 & 13 & 10 & $\begin{array}{l}\text { Not all products in the food and } \\
\text { processing industry show a positive } \\
\text { trend, some indicators have not } \\
\text { changed significantly since } 2012 \text {. }\end{array}$ \\
\hline 5 & $\begin{array}{l}10 \text { (2 for each } \\
\text { type of } \\
\text { product) }\end{array}$ & 6 & 6 & $\begin{array}{l}\text { Low sales of crop production and the } \\
\text { lack of storage capacity for these } \\
\text { products have a negative impact on } \\
\text { the level of food security in the } \\
\text { region due to the high risks of losses. }\end{array}$ \\
\hline 6 & 10 & 4 & 2 & $\begin{array}{l}\text { The self-sufficiency of the region } \\
\text { with food products in } 3 \text { indicators } \\
\text { (meat, milk, vegetables) is below the } \\
\text { threshold values. } \\
\text { In } 2016 \text {, self-sufficiency was also } \\
\text { below the threshold for potatoes. }\end{array}$ \\
\hline 7 & $\begin{array}{l}14 \text { ( } 2 \text { points } \\
\text { for each type } \\
\text { of product) }\end{array}$ & 13 & 6 & $\begin{array}{l}\text { Indicators of low-quality and } \\
\text { dangerous products are significantly } \\
\text { reduced for all types of products, } \\
\text { with the exception of bakery } \\
\text { products. }\end{array}$ \\
\hline 8 & 2 & 0 & 0 & $\begin{array}{l}\text { There is a lack of support for the } \\
\text { poor in terms of the amount of } \\
\text { budget funds allocated by more than } \\
2 \text { times }\end{array}$ \\
\hline 9 & 2 & 2 & 2 & $\begin{array}{l}\text { The volume of state support over the } \\
\text { past } 5 \text { years has shown positive } \\
\text { dynamics and belongs to the most } \\
\text { important types of products for the } \\
\text { region }\end{array}$ \\
\hline 10 & 4 & 0 & 4 & $\begin{array}{l}\text { In the region, there is a lack of } \\
\text { availability of areas used for the sale } \\
\text { of food products in retail markets, as } \\
\text { well as areas in public catering } \\
\text { establishments. }\end{array}$ \\
\hline TOTAL: & 102 & $63(61,7 \%)$ & $\begin{array}{c}56 \\
(54,9 \%)\end{array}$ & $\begin{array}{l}\text { Class III: acceptable level of food } \\
\text { security in } 2018\end{array}$ \\
\hline
\end{tabular}




\section{Conclusions}

Thus, the current state of food security in the Sverdlovsk region in 2018 is estimated at an acceptable level with acceptable risks for self-sufficiency in food for this region. In comparison with 2016, in which class IV was diagnosed, a low level, in 2018, there is a strengthening of food security. It can be noted that there is a strong relationship between the development of the agro-industrial complex and the level of food security in the region. As a result, with the improvement of the state of the agro-industrial complex in the region, we can expect to strengthen food security in the same territory. Based on the problems identified in the course of the analysis and assessment of the level of food security in the Sverdlovsk region: a decrease in production volumes, an increase in consumption, and the low competitiveness of some types of agricultural products both on foreign and domestic markets, we can assume the main vectors of the activities of the regional authorities to further strengthen its food security.

\section{References}

1. V.G. Gusakov, Agrar. Economy 2 (297), 3 (2020)

2. G. Rasul, Managing the food, water, and energy nexus for achieving the Sustainable Development Goals in South Asia. Environmental Development 18, 14 (2016)

3. Rome Declaration on World Food Security (Rome, 13.11.1996). http://www.g20civil.com

4. A.V. Kuchumov, Food supply of regions as the basis of food security in Russia: monograph (INFRAM, 2018). http://znanium.com/catalog/product/969832, free.

5. T.N. Filonova, Central Russian Bulletin of Social Sciences 4(34), (2014)

6. G. V. Gusakov, N. V. Karpovich, L.T. Yonchik, L.A. Lobanova, I.V. Gusakova, Vestsi Natsyyanal'nay akademii navuk Belarusi. Seryya agrarnykh navuk. Proceedings of the National Academy of Sciences of Belarus. Agrarian series 58(3), 268 (2020)

7. T.V. Uskova, Agroindustrial complex of the region: state, trends, prospects: monograph, Vologda: ISERT RAN, 136 p. (2013)

8. J. D. Gil, P. Reidsma, K. Giller, L. Todman, A. Whitmore, and M. van Ittersum, Ambio 48 (7), 685 (2019)

9. R. Perez-Escamilla, Curr. Dev. Nutr. 1(7) (2017)

10. G. Haysom, G. Tawodzera? Measurement drives diagnosis and response, Gaps in transferring food security assessment to the urban scale Food Policy 74, 117 (2018)

11. G. Forero-Cantor, J. Ribal, N. Sanjuán, Agric. Econ. - Czech 66, 112 (2020)

12. M. Bobe, R. Procopie, and M. Bucur, Amfiteatru Economic, 21(51), 347 (2019)

13. T.V. Uskova, Food security of the region: monograph (ISEDT RAS, 2014) 